\title{
Pendekatan Interdisiplin dalam Pengembangan Kesadaran Gaya Hidup Bijak dan Ramah Lingkungan
}

\author{
Aris Munandar, Karlina Maizida, Rahmawan Jatmiko \\ Departemen Antar Budaya, Fakultas Ilmu Budaya, Universitas Gadjah Mada \\ Korespondensi: arismunandar@ugm.ac.id
}

\begin{abstract}
The rapid development of technology triggers attitudes and behaviors of consumerism. The two things have a cause and effect relationship that cause multiple pressures on the environment in the form of resource exploitation to support innovation, and waste from innovation products of short use duration to meet consumer desires. Therefore, it is necessary to be aware of consumerism behavior that is triggered by the innovation of various technology products and their impact on the environment. With this awareness, it is expected that the community can develop a wise and environmentally friendly lifestyle as an effort to reduce the rate of exploitation of natural resources and increase the uncontrolled waste of technological innovation products. The interdisciplinary approach by combining cultural sciences and psychology provides a formulation of conceptual and practical solutions to environmental problems due to consumerism that is increasingly rampant both in urban and rural areas. This interdisciplinary approach applied in the community service program for the labor force group provides sustainable benefits because it increasingly empowers this group in disseminating wise and environmentally friendly lifestyles to the living environment and work environment.
\end{abstract}

Keywords: Interdisciplinary approach; consumerism; environmental problems; labor force

\begin{abstract}
Abstrak
Perkembangan teknologi yang pesat memicu sikap dan perilaku konsumerisme. Kedua hal yang memiliki hubungan sebab akibat tersebut menimbulkan tekanan yang berlipat ganda terhadap lingkungan berupa eksploitasi sumber daya untuk mendukung inovasi dan limbah dari produk inovasi berdurasi pemakaian pendek untuk memenuhi hasrat konsumen. Oleh karena itu, perlu penyadaran akan perilaku konsumerisme yang dipicu oleh inovasi beragam produk teknologi serta dampaknya bagi lingkungan. Dengan kesadaran ini diharapkan masyarakat dapat mengembangkan gaya hidup yang bijak dan ramah lingkungan sebagai upaya menekan laju eksploitasi sumber daya alam serta peningkatan limbah produk inovasi teknologi yang tidak terkontrol. Pendekatan interdisipliner dengan menggabungkan ilmu budaya dan psikolog memberikan rumusan solusi yang bersifat konseptual dan praktis bagi persoalan lingkungan akibat perilaku konsumerisme yang semakin merajalela baik di daerah perkotaan maupun pedesaan. Pendekatan interdisipliner ini diterapkan dalam program pengabdian kepada masyarakat bagi kelompok angkatan kerja dalam memberikan manfaat yang berkelanjutan karena semakin memberdayakan kelompok ini dalam menyebarluaskan gaya hidup bijak dan ramah lingkungan kepada lingkungan tempat tinggal maupun lingkungan kerja.
\end{abstract}

Kata kunci: Pendekatan interdisipliner; konsumerisme; persoalan lingkungan; angkatan kerja 


\section{Pendahuluan}

Keterkaitan antara inovasi produk, gaya hidup konsumerisme, dan kerusakan lingkungan belum dipahami dengan baik oleh sebagian (besar) masyarakat Indonesia. Inovasi produk yang seolah tidak ada hentinya dipersepsikan sangat positif sehingga mendapatkan dukungan tanpa disertai kontrol terhadap eksploitasi sumber daya alam. Produk baru menuntut pembeli (konsumen) maka berbagai strategi pemasaran dilakukan, terutama melalui media. Jangkauan media yang luas sampai ke daerah pedesaan memberikan pengaruh yang sangat besar terhadap sikap dan perilaku masyarakat. Kemampuan visual media mampu membius konsumen dan akhirnya menjerat konsumen ke dalam perangkap hasrat untuk memiliki, menggunakan, dan kemudian membuang. Hasrat demikian memberikan dampak yang membahayakan tidak hanya bagi kesehatan mental, tetapi juga lingkungan. Usia pakai suatu produk menjadi lebih pendek dan akibatnya volume limbah terus meningkat. Sementara itu, teknologi pengolahan (pemanfaatan) limbah tidak berkembang secepat inovasi produk. Muncullah permasalahan lingkungan yang semakin hari semakin serius.

Hingga saat ini, upaya memutus mata rantai inovasi $\rightarrow$ konsumerisme $\rightarrow$ degradasi kualitas lingkungan belum menunjukkan hasil yang memuaskan. Salah satu upaya yang diharapkan mampu mengatasi persoalan ini adalah perubahan sikap masyarakat terhadap inovasi serta kesadaran akan dampak inovasi terhadap gaya hidup dan kualitas lingkungan. Apabila masyarakat yang menjadi target pemakai produk inovasi tidak mudah tergiur oleh inovasi baru yang sebetulnya tidak terlalu berbeda dengan produk inovasi pendahulunya, laju inovasi dapat diperlambat. Eksploitasi sumber daya alam yang digunakan untuk membuat produk inovasi dapat ditekan dan volume limbah pun dapat dikurangi.

Oleh karena itu, upaya menumbuhkan kesadaran masyarakat untuk mengadopsi gaya hidup yang bijak dan peduli lingkungan sangat mendesak dilakukan. Kelompok masyarakat yang rentan terhadap gaya hidup konsumerisme adalah kelompok angkatan kerja yang akan segera mendapatkan kemandirian finansial. Dengan kemandirian finansial, mereka lebih mudah tergoda untuk mengonsumsi produk inovasi baru. Sebelum benar-benar mendapatkan kemandirian finansial, mereka perlu mendapatkan pengetahuan dan keterampilan untuk mengembangkan gaya hidup yang bijak dan ramah lingkungan.

\section{Pedekatan Pelaksanaan Program}

\section{Globalisasi dan Perubahan Sosial}

Dewasa ini, Indonesia menghadapi permasalahan kompleks yang berkaitan dengan globalisasi dan perubahan sosial budaya yang sangat cepat. Sesungguhnya, globalisasi (menuju pada budaya global) merupakan gerak kebudayaan yang tidak mengenal batas negara maupun ideologi sehingga dapat menyebar hingga ke pelosok Nusantara melalui industri budaya. Perubahan sosial budaya yang cepat dan kurangnya kesiapan masyarakat Indonesia dikhawatirkan dapat melemahkan peradaban, seperti etika sosial, budi pekerti, dan sebagainya. Ukur (via Suwondo, 1982:5) meyakini bahwa salah satu penyebab timbulnya banyak kesulitan dalam usaha membangun masyarakat dalam 
rangka modernisasi dewasa ini adalah kekurangmampuan kita memahami cara berpikir, menanggapi, merasa, mengutarakan, dan sebagainya dari suatu kelompok masyarakat.

Modernisasi tidak semata-mata dikaitkan dengan ketersediaan fasilitas hidup yang modern, tetapi juga pola pikir yang maju. Pola pikir yang maju dapat membawa pada peradaban yang semakin tinggi di satu sisi, tetapi di sisi lain membawa dampakdampak yang negatif terhadap lingkungan alam, antara lain, eksploitasi sumber daya alam untuk memproduksi fasilitas hidup yang modern. Kepahaman mengenai segi baik dan segi buruk dari modernisasi akan memberikan kemampuan masyarakat memilah dan memilih sikap serta perilaku yang positif. Sikap dan perilaku yang diharapkan terbentuk adalah kepedulian terhadap lingkungan.

Budaya global, pada kenyataannya bukanlah sebuah konsep genealogis yang menjelaskan sebuah fenomena kebudayaan yang lahir atau mengakar pada sebuah teritorial tertentu, sebagaimana misalnya ketika kita membicarakan budaya Jawa. Dalam kerangka inilah, Roland Robertson melihat budaya global sebagai fenomena kebudayaan yang terbentuk oleh berbagai komponen citra dan definisi-definisi yang saling bertarung serta berkonflik. Oleh karena itu, budaya global sering dilihat sebagai sebuah fenomena '... kepentingan historis dunia yang berbahaya', khususnya bagi eksistensi dan keberlangsungan budaya-budaya lokal yang bersifat otentik dan asli (Suwondo, 1982:385).

Globalisasi dianggap oleh berbagai pihak telah menimbulkan berbagai tantangan dan ancaman bagi keberlanjutan budaya-budaya lokal pada masa depan. Meskipun demikian, tidak semua orang berpandangan bahwa globalisasi hanya menciptakan homogenisasi budaya atau kloning budaya dan, dengan demikian, dilihat sebagai sebuah ancaman serius bagi keberadaan budaya-budaya lokal. Gurnah (via Piliang, 2005:292293), misalnya, melihat globalisasi budaya tidak sesederhana sebagai sebuah homogenisasi budaya. Apa yang dilihatnya adalah proses seleksi, pertukaran, dan pengaruh interkultural yang rumit dan kompleks, yang justru dapat bersifat positif, konstruktif, dan produktif bagi perkembangan budaya lokal (Piliang, 2006:292—293).

\section{Sikap Peduli pada Kelestarian Lingkungan}

Kegiatan pengabdian dengan tema penguatan kemampuan merespons perubahan sosial dalam kelompok angkatan kerja pada era globalisasi ini bertujuan untuk memberikan pembekalan pengetahuan lintas budaya dan penyadaran akan pentingnya kearifan lokal serta nilai-nilai moral kepada generasi muda di Kabupaten Sleman, dalam konteks pelestarian lingkungan hidup. Budaya global (global culture) adalah sebuah konsep yang menjelaskan tentang mendunianya berbagai aspek kebudayaan, yang di dalam ruang global tersebut terjadi proses penyatuan, kesalingberkaitan, dan kesalingterhubungan. Oleh sebab itu, budaya global sering diidentikkan dengan proses penyeragaman budaya atau imperialisme budaya (Piliang, 2006:85). Salah satu bagian dari budaya global adalah gaya hidup konsumerisme.

Pengalaman sebuah kebudayaan bergaul dengan kebudayaan asing, menurut Gurnah, semuanya bersifat parsial, tidak pernah superfisial dan total. Jarang sekali sebuah kebudayaan asing-yang selama ini disebut imperialis-dapat menggantikan atau mengambil alih kebudayaan lokal. Bahkan, kebudayaan tersebut dapat secara signifikan menyumbang bagi pengembangan pandangan dunia sebuah masyarakat lokal. Apa yang membuat orang-orang di negara-negara berkembang begitu antusias 
terhadap budaya imperialis adalah hasrat yang aktif untuk mengonstruksi common denominator kebudayaan yang khas, kuat, dan saling menguntungkan dengan budaya tersebut melalui proses pertukaran budaya (cultural exchange). Proses pertukaran budaya tersebut dapat menciptakan budaya-budaya baru, dalam sebuah hubungan yang terusmenerus paradoksal: global/lokal, tradisi/kemajuan, masa lalu/masa depan. Akan tetapi, proses pertukaran ini tidak pernah menggiring pada keseragaman atau kloning. Pola-pola yang berubah di dalam kebudayaan yang berbeda tidak pernah dapat memproduksi satu sama lainnya karena mereka dibentuk dari bahan-bahan baku kebudayaan yang berbeda, yang ditempa di dalam sejarah yang beraneka ragam pula (Piliang, 2006:292-293).

Mengingat luasnya cakupan pengertian globalisasi dan budaya global, $\mathrm{PkM}$ (Pengabdian kepada Masyarakat) ini menentukan fokus kegiatannya pada konsep green-living yang sedang menjadi tren pemikiran masyarakat global sebagai respons terhadap penurunan kualitas lingkungan yang diakibatkan antara lain oleh gaya hidup konsumerisme. PkM ini bertujuan menggali budaya green living, yang sebetulnya ada pada budaya tradisional Indonesia, dan menguatkannya dengan konsep green living yang ada pada budaya di negara maju sehingga tercipta keselarasan antara budaya lokal dan budaya global.

\section{Pendekatan Interdisipliner Ilmu Budaya dan Psikologi}

Degradasi kualitas lingkungan merupakan persoalan yang kompleks. Penalaran yang sederhana dapat menjelaskan kerumitan persoalan ini: adanya sampah yang dibuang sembarangan hanya akan terselesaikan apabila tersedia tempat sampah yang mudah dijangkau, pengangkutan sampah ke lokasi pembuangan akhir, serta kesadaran masyarakat akan sanitasi lingkungan sehingga berperilaku membuang sampah pada tempatnya dan bersedia membayar iuran sampah. Dengan demikian, solusinya tidak boleh parsial dengan hanya menyediakan tong-tong sampah. Solusi yang komprehensif dapat terumuskan melalui pendekatan interdisipliner, bahkan multidisipliner.

Setiap bagian dari solusi yang komprehensif terhadap persoalan lingkungan pun harus dirumuskan dengan pendekatan interdisipliner. Dengan kata lain, kesadaran terhadap gaya hidup yang bijak dan ramah lingkungan sebagai salah satu bagian dari solusi persoalan lingkungan dapat ditumbuhkan melalui pendekatan interdisipliner, misalnya antara ilmu budaya dan psikologi. Ilmu budaya akan menggali kearifan lokal yang dimiliki oleh budaya Indonesia dan psikologi mengidentifikasi potensi individu untuk mengembangkan kearifan lokal menjadi perilaku atau karakter individu yang hidup pada era globalisasi sekarang ini.

\section{Pelaksanaan Program}

\section{Tabap Persiapan}

Tim pengabdian mengadakan survei lapangan untuk melakukan analasis kebutuhan. Dari analisis kebutuhan diketahui bahwa Balai Latihan Kerja Kabupaten Sleman membutuhkan materi bagi peserta pelatihan pengetahuan dan keterampilan untuk bersikap arif dalam menyikapi perubahan gaya hidup akibat globalisasi. Oleh karena itu, tim $\mathrm{PkM}$ menyiapkan materi dan instrumentasi kegiatan berupa sumber audio visual untuk menanamkan sikap arif (nonkonsumeris) ke arah gaya hidup yang bijak terhadap lingkungan. 


\section{Tahap Pelaksanaan}

Kegiatan Pengabdian kepada Masyarakat dapat dilaksanakan melalui kerja sama dengan Balai Latihan Kerja (BLK) Kabupaten Sleman. Seluruh rangkaian kegiatan diselenggarakan di auditorium Balai Latihan Kerja kabupaten Sleman.

Pengembangan kesadaran gaya hidup yang bijak dan ramah lingkungan dilakukan melalui dua tahapan, yaitu tahap pemerolehan pengetahuan serta tahap internalisasi pengetahuan menjadi sikap dan perilaku.

a. Pemerolehan pengetahuan

Pemerolehan pengetahuan dilakukan melalui pemaparan dan diskusi mengenai jenis-jenis gaya hidup beserta dampaknya, baik terhadap individu, masyarakat, maupun lingkungan. Pada tahap ini dikembangkan dua modul, yaitu "Gaya Hidup dan Konsumerisme” dan "Pengaruh Gaya Hidup Konsumerisme terhadap Kesehatan Mental“

b. Internalisasi pengetahuan

Internalisasi pengetahuan dilakukan melalui simulasi yang membangun daya nalar kritis serta daya kreativitas seseorang ketika menghadapi masalah konkret yang berkaitan dengan pelestarian lingkungan. Dalam tahap ini dikembangkan enam situasi untuk simulasi.

\section{Situasi 1}

Saya akan mendapatkan penghasilan sendiri. Sudah ada rencana untuk membeli beberapa barang elektronik model terbaru untuk mengganti yang sudah ada.

Apakah rencana itu sebaiknya saya wujudkan setelah mendapatkan penghasilan sendiri?

Bagaimana saya mengelola penghasilan saya secara bijak pada bulan-bulan selanjutnya?

\section{Situasi 2}

Saya membeli kulkas dan mesin cuci baru. Setelah kulkas dan mesin cuci terpasang, apa yang harus saya lakukan dengan kardus dan styrofoam pembungkus kulkas tersebut?

a. Meminta agar kardus dan styrofoam dibawa kembali ke toko.

b. Membuangnya di tempat sampah

c. Membakarnya

d. Menyimpannya untuk digunakan suatu saat

Apa pertimbangannya?

\section{Situasi 3}

Setiap melalui jalan utama di kampung saya, saya melihat bungkusan sampah dalam tas plastik yang sengaja dibuang oleh pengendara motor.

Sudah dipasang tulisan "Denda 1 juta bagi yang membuang sampah liar", "Jangan membuang sampah di sini", dll., tetapi tidak ada perubahan.

Bagaimana cara saya mengatasi masalah ini? 


\section{Situasi 4}

Saya memiliki gagasan untuk membuat bank sampah di kampung saya. Bank sampah saya yakini dapat mengatasi persoalan sampah di kampung saya. Akan tetapi, bagaimana saya mewujudkan gagasan saya ini?

\section{Situasi 5}

Sudah ada 2 orang warga di kampung saya yang siap mengambil sampah dari rumahrumah penduduk setiap hari dan membawanya ke TPA. Akan tetapi, belum semua rumah mau membayar iuran bulanan, padahal mereka tidak memiliki halaman untuk membuat lobang pembuangan sampah. Bisa diduga, mereka membuang sampah sembarangan.

Apa yang harus saya lakukan agar semua rumah mau membayar iuran sampah sehingga akan ada yang membantu membawa sampah dari setiap rumah ke TPA?

\section{Situasi 6}

Saya akan membeli burger untuk oleh-oleh. Saya lihat ada 2 jenis bahan pembungkus burger: styrofoam dan plastik transparan.

Pembungkus mana yang sebaiknya saya pilih?

Saya mengetahui bahwa pembungkus dari bahan kertas lebih ramah lingkungan. Apa yang dapat saya lakukan untuk membujuk penjual burger agar beralih ke pembungkus berbahan kertas?

Fokus simulasi adalah kemampuan mendeskripsikan situasi, mengidentifikasi persoalan, dan merumuskan solusi yang bersifat praktis. Simulasi dilakukan secara berkelompok sehingga respons terhadap situasi mencerminkan respons kolektif sebagaimana kearifan lokal yang terbentuk dalam kebudayaan suatu masyarakat.

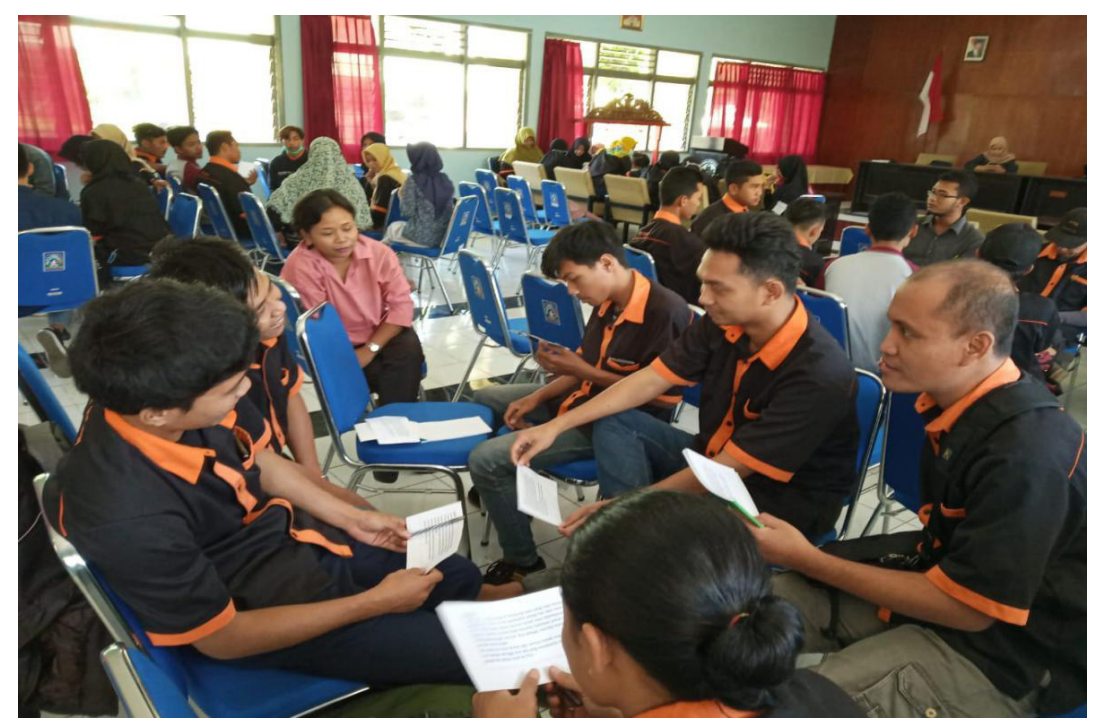

Gambar 1. Tahap memahami situasi. 


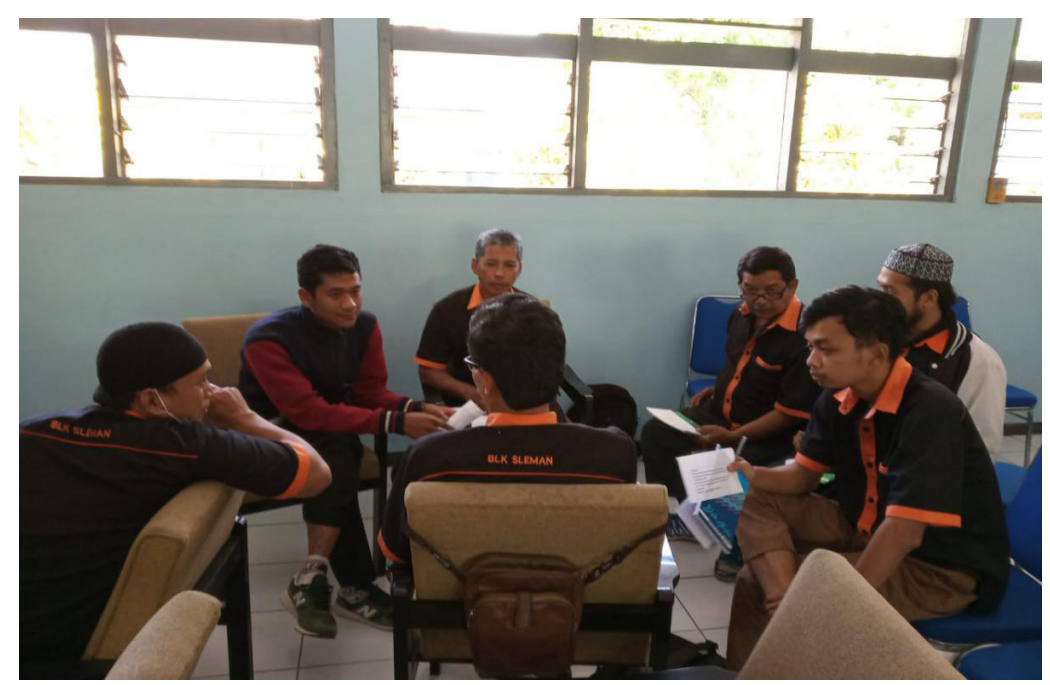

Gambar 2. Tahap merumuskan respon terhadap situasi.

\section{Refleksi Capaian Program}

Dari pelaksanaan kegiatan pengabdian masyarakat ini tercapai hal-hal berikut.

a. Angkatan Kerja di Kabupaten Sleman memiliki bekal pengetahuan pemahaman lintas budaya untuk merespons perubahan sosial secara bijak dan cerdas.

b. Angkatan Kerja di Kabupaten Sleman memiliki contoh model gaya hidup ramah lingkungan selaras dengan nilai-nilai moral baik di lingkungan kerja maupun tempat tinggalnya.

c. Angkatan kerja dapat merancang program implementasi Green Living untuk mengatasi persoalan lingkungan di sekitarnya.

\section{Penutup}

Upaya menumbuhkan kesadaran untuk mengembangkan gaya hidup bijak dan ramah lingkungan harus menjadi salah satu prioritas penyelesaian permasalahan sosial budaya akibat globalisasi. Gaya hidup yang bijak dan ramah lingkungan dapat menyelesaikan berbagai persoalan, antara lain, seperti kriminalitas yang dipicu oleh ketidakmampuan (secara ekonomi) untuk mewujudkan gaya hidup modern, kesenjangan sosial yang semakin melebar, dan kerusakan lingkungan yang serius. Pendekatan interdisiplin antara ilmu budaya dan psikologi dapat lebih mengoptimalkan tumbuhnya kesadaran untuk mengembangkan gaya hidup bijak dan ramah lingkungan, khususnya pada kelompok angkatan kerja yang pada saat bersamaan sedang mengalami krisis identitas.

\section{Daftar Pustaka}

Piliang, Y.A. (2006). Dunia yang Dilipat: Tamasha Melampaui Batas-batas Kebudayaan. Yogyakarta dan Bandung: Jalasutra.

Suwondo, B. (Ed). (1982). Cerita Rakyat Daerah Istimewa Yogyakarta. Yogyakarta: Departemen Pendidikan dan Kebudayaan DIY. 